\title{
(Q)
}

\section{Judicial Independence and Perceptions of Judicial Independence}

\begin{abstract}
The three key concepts of this study are: perceived judicial independence, respect for judicial independence and trust in the judiciary. To provide the basis for the empirical chapters that follow, theoretical considerations are explored. Due to the subjective nature of independence, perceptions matter. According to European case law, the appearance of independence needs to be taken into account when the independence of a court is evaluated. The perceptions held by parties, lawyers, media, general public and judges are not homogeneous, and depend on different sets of factors. In the literature, it is widely believed that the judiciary needs a positive perception of independence to gain the trust of society. This trust in turn bolsters the legitimacy of the judiciary. Trust and legitimacy are many-faceted concepts. In this study trust is used in the sense of diffuse institutional trust. Respect for independence is used as an expression of the legitimacy of the judiciary. These concepts apply to the national courts and to the courts at the EU/European level. To understand judicial independence in Europe, both levels need to be examined in conjunction.
\end{abstract}

Keywords Judicial independence - Impartiality · Trust - Respect . Multilevel governance 


\subsection{Relevance of Perceptions OF JUDICIAL INDEPENDENCE}

Independence is the core principle and value of the judiciary and also its performance yardstick. This is expressed in many basic documents. Focusing on Europe, Article 6(1) ECHR states that "in the determination of his civil rights and obligations or of any criminal charge against him, everyone is entitled to a fair and public hearing within a reasonable time by an independent and impartial tribunal established by law". As the current president of the Court of Justice of the European Union puts it succinctly, “... the principle of judicial independence constitutes the essence of the fundamental right to effective judicial protection" (Lenaerts 2020, p. 32). This function of independence follows from the division of power among the branches of the state to protect citizens in disputes with the state. However, the emphasis on independence also derives from the raison d'être of the judiciary to adjudicate any dispute fairly, in a predominantly confrontational setting. The courts take far reaching decisions about people and their lives. Parties-often very unequal in resources and power-disagree and quarrel, often in a highly charged and emotional atmosphere. To put it simply, they want to win (or at least not lose), and are often willing to go to extremes to achieve this. This confrontational aspect distinguishes the judiciary from most other professional organizations, and puts the independence of the judge at the forefront. A judge cannot be an effective arbitrator if she is not independent and impartial, and is seen as such by the parties.

Independence is a multi-faceted phenomenon. The case law of the highest European courts, the Court of Justice of the European Union and European Court of Human Rights, give insight in what is seen as particularly important. According to the Court of Justice: “... in order to establish whether a tribunal is 'independent' within the meaning of Article 6(1) of the ECHR, regard must be had, inter alia, to the mode of appointment of its members and their term of office, the existence of guarantees against outside pressures and the question whether the body at issue presents an appearance of independence...". ${ }^{1}$ While this statement does not constitute a definition of independence or a full description of relevant factors, it provides a useful insight into what is currently on top of

${ }^{1}$ CJEU, Combined Cases C-585/18, C-624/18 and C-625/18, ECLI:EU:C:2019:982, Judgment of 19 November 2019, para. 127. 
the mind of leading justices. Appearances is one of them. This statement also reflects different concepts of independence. The aim of the Court of Justice is to establish the actual independence of a court in a specific case. To do this it singles out the mode of appointment of judges and the existence of guarantees of independence. These aspects are part of, what is often called, the de iure independence of the judiciary: the formal arrangements that shape and protect the independence of the judiciary. There are many more aspects of de iure independence than mentioned here (see for instance the indicator system of the ENCJ for an exhaustive list [ENCJ 2020]). The Court also refers to the appearance of independence. How parties and others perceive the independence of the judge(s) in the case at hand is important. The Court of Justice has set a high standard: regarding guarantees rules should be set "in order to dispel any reasonable doubt in the minds of individuals as to the imperviousness of that body to external factors and its neutrality with respect to the interests before it." 2

The prominent role of perceptions reflects the difficulties for those involved in procedures to establish in a straightforward manner whether or not judges are independent. Ideally, one would like to establish 'objectively' the actual independence of judges as it shows in their behaviour and decisions: in judges' behaviour in court (how they conduct hearings) and, in particular, in their judgments. These judgments should 'prove' the extent to which they are being led only by the law, and to this end are 'impervious' to inappropriate external (political and private) pressures and internal pressures (from other judges and management). This is for several reasons, apart from the technical nature of legal issues, difficult to do. Being led only by the law means that political, religious or other background does not play a role in adjudicating cases. While background may not play a large role in most run-of-the mill cases (Ashenfelter et al. 1995), it becomes an issue in controversial cases. The Chief Justice of the US in his reply to criticism of the President of that country on alleged political bias of a judge who ruled against a migrant asylum order of the President, expresses this aspiration clearly: "We do not have Obama judges or Trump judges, Bush judges or Clinton judges. What we have is an extraordinary group of dedicated judges doing their level best to

${ }^{2}$ CJEU, Case C-216/18, ECLI:EU:C:2018:586, Judgment of 25 July 2018, para. 66. 
do equal right to those appearing before them". ${ }^{3}$ This goal puts high demands on the way judges are selected and promoted: selection needs to be based on merit (knowledge and experience), and not on other (such as political) considerations. However well this selection is done, reality is that judgments reflect values anyway. The extent to which judges are able and willing to abstract from their convictions and their backgrounds is an empirical question but hard to research, let only be established in the heat of the court case by the court users in anything close to objectivity.

The second aspect, being impervious to pressure, is equally subjective. It is made complicated by the qualifier 'inappropriate'. If it comes to corruption in its diverse forms, it is by definition that this is inappropriate pressure (including temptation), and the relevance of safeguards against such outside pressure is evident. Otherwise, there will always be pressure for instance by the media, and undergoing pressure-appropriate and inappropriate-from all sides and withstanding it, is part of being a judge. This resilience is to be achieved not by judges isolating themselves from society, as they are expected to be in touch with society (Warner et al. 2014). How else can a judge know how deeds that come before the bench affected society? When external pressure becomes inappropriate is arbitrary and subjective. Similarly, internal pressures on judges may come from a court president who puts pressure on a judge to decide a case in a certain way, but the court president may also enquire about the delay in a court case or from colleagues who together agree on a guideline for the penalty for a certain type of crime. Again, what is inappropriate is arbitrary and subjective.

Given these and other inherently subjective aspects, it is relevant how judicial independence is perceived in individual court cases as stipulated in the reasoning of the Court of Justice, but it is also relevant at an aggregate level to evaluate the independence of the judiciary as a whole. Systematic measurement is needed for this purpose not only of the perceptions of the parties, but also of the perceptions of other categories such as lawyers, media, general public as well as judges themselves. The perceptions of a variety of actors are relevant in particular because they see different parts of reality, have different interests and stakes, and are likely to be subject to different biases.

${ }^{3}$ Roberts as quoted by AP, 22 November 2018. 
Perceptions of judges are, for instance, informative about the pressures they are under, but may be less so to capture whether they are influenced by their beliefs. The perceptions of parties and lawyers are directly relevant, but their perspectives may be heavily influenced by (expected) outcomes, while the perceptions of the media are similarly relevant, but may be biased towards sensationalist reporting. The perceptions of the general public are likely to be diffuse, but in a democracy essential to understand the role given to the judiciary in society.

\subsubsection{Independence and Impartiality}

Independence and impartiality are often used in combination. The already quoted Art 6(1) ECHR offers an example. The two terms are used next to each other, and the relationship between the two needs to be clarified here. While independence refers to a general state of mind but also to institutional arrangements, impartiality relates to the state of mind of the court (the judge) towards the issues and parties in a case $\mathrm{OHCHR}$ 2003). No prejudice, preference or bias is to be expressed in any way at hearings or otherwise. As for independence, the case law of the Court of Justice gives an indication what impartiality entails in the view of the court:

... impartiality can, according to equally settled case-law of the European Court of Human Rights, be tested in various ways, namely, according to a subjective test where regard must be had to the personal convictions and behaviour of a particular judge, that is, by examining whether the judge gave any indication of personal prejudice or bias in a given case; and also according to an objective test, that is to say by ascertaining whether the tribunal itself and, among other aspects, its composition, offered sufficient guarantees to exclude any legitimate doubt in respect of its impartiality. As to the objective test, it must be determined whether, quite apart from the judge's conduct, there are ascertainable facts which may raise doubts as to his or her impartiality. In this connection, even appearances may be of a certain importance. ${ }^{4}$

${ }^{4}$ CJEU, Combined Cases C-585/18, C-624/18 and C-625/18, ECLI:EU:C:2019:982, Judgment of 19 November 2019, para 128. 
The Court of Justice attaches importance to appearances, like with independence. Independence and impartiality are closely linked and overlapping concepts. It is assumed here that the independence of the judge in a case is a necessary but not sufficient condition for her impartiality in that case. It is questionable whether the parties can recognize whether a judge is independent. It is more likely that parties can recognize whether a judge is impartial or not. Impartiality is then an imperfect indicator of independence. In existing court user surveys in as far as these surveys address such fundamental matters (which they normally do not), the relevant question is about impartiality (Netherlands, US) or neutrality (Denmark).

\subsection{Formation of Perceptions of Independence}

The formation of perceptions of judicial independence varies among categories of actors. Delivering justice differs from receiving justice, and direct personal experience differs from indirect information through social networks or the media. To start with the parties, according to the extensive literature on procedural justice the neutrality of the decision maker is one of four key aspects that determine the fairness of a procedure, the others being voice, respect and trustworthiness (see the review of Tyler and Sevier 2013/2014). Thus, the independence and impartiality of the judge are an integral part of the procedural justice attained by the courts (also, Grootelaars and van den Bos 2018; CEPEJ 2016). Ideally, procedures are conducted in such a way that also the losing parties are satisfied with the fairness of the procedure. While they may not agree with the outcome, they accept the judicial decisions, implement them voluntarily and support the courts (Tyler and Sevier 2013/2014). The expectation would be that, if procedural fairness is realized to a high degree, the satisfaction with the court among the parties that the court ruled in favour of and among the parties it ruled against would not differ much. This would then also be the case for perceptions of independence.

Reality is often different. With fair procedures, it may be possible to achieve-but it is by no means guaranteed - that both parties appreciate the interaction as fair, and evaluate the experience as positive, irrespective of winning or losing. This positive experience would lead to an improvement of sentiments among the parties and positive sentiments towards the court. In other situations, the interaction will be evaluated negatively by the losing party, strengthening the negative sentiments about the other 
party and creating negative sentiments about the court. ${ }^{5}$ This extends to the perception of independence. In addition, when parties lose their case, they or their lawyers are tempted to rationalize the loss by assuming that the judge was partial and not really independent. 'Justice must be seen to be done', but do losing parties recognize justice when it is done? A survey among court users in the Netherlands shows significant differences between winners and losers with respect to their experience, even if in both groups most respondents are positive about the experience. ${ }^{6,7}$ As losing weighs heavier than winning (Kahneman and Tversky 1984) and in general negative events weigh heavier than positive events (Baumeister et al. 2001), it is not assured that what is expressed in surveys is a true representation of judicial independence. A negative bias is more likely. While lawyers are partisan as well, they will be less emotionally involved than the parties, have realistic expectations about what to expect and by being a lawyer are less put off by complex, formalistic legalities. Their perspective could therefore be less biased.

As to perceptions among the general public, most citizens have infrequent contact with the courts (see Sect. 3.5). As most people do not have recent, direct personal experience with the courts, the experiences and beliefs of those who have such experiences, translate into public opinion about the independence of the judiciary by means of interpersonal networks, reporting on social and traditional media and through the political arena. In the traditional media and social media negative experiences with the courts are likely to be accentuated. This holds for all media but in particular for what may be called sensationalist media (Johnston and Bartels 2010). Politicians may react to critical opinions of aggrieved court users, especially when re-enforced by the media. They may also have their own agendas with regard to democracy and the balance of the state powers, which may or may not respect each other's role. The (dis)respect shown by relevant actors for the independence of the judiciary is likely

${ }^{5}$ See van Dijk et al. (2002) on the development of positive and negative sentiments as a result of social interaction.

${ }^{6}$ Parties for whom the judgement is (expected to be) favourable are significantly more often positive about the performance of the judiciary than parties seeking justice for whom the judgement is (expected to be) unfavourable: respectively, $90 \%$ and $62 \%$ are (very) satisfied and $3 \%$ and $14 \%$ are (very) dissatisfied (Regioplan and Ipsos 2015).

${ }^{7}$ The CEPEJ 2016 model questionnaire includes for court users a question whether the court found in favour of the court user concerned (CEPEJ 2016). 
to affect public opinion. While it is the duty of all governmental and other institutions to respect and observe the independence of the judiciary (OHCHR 1985), in reality otherwise can be observed. An example for the United States was already given. In Europe Poland is a particular case in point (i.a. Venice Commission 2020). Thus, the perceptions of the general public about the independence of the judiciary are an amalgam of influences. It should be stressed that the perceptions of the general public are particularly relevant as these inform decisions of individuals to bring cases to court, to refrain from legal action or, if available, to use other methods of dispute resolution. These perceptions will also play a role in political decisions about the legal system. Given the function of the courts in economic interaction, the views within the business sector are similarly relevant.

Finally, the judges themselves. They have not (or are not supposed to have) a vested interest in court cases like the parties and lawyers. They have first-hand experience with the practical implementation of formal guarantees of independence, the actual pressures (and temptations) on judges from outside and inside the courts, but also how judges personally or as a group react to pressure. The downside is, of course, that they have to evaluate themselves and their colleagues, and, while judges are trained to be cool observers, whether they can do that when it concerns themselves or their group is another matter.

To conclude, the perceptions of the categories of stakeholders that were discussed, are formed by very different mechanisms. As a consequence, their perceptions have different characteristics and biases, and their combination is necessary to construct a full picture. Together the perceptions can shed light on the elusive 'de facto' independence of the judiciary. In addition, actors that bridge boundaries are of particularly relevance here. In Chapter 4 the perceptions of lay judges are discussed.

\subsection{Independence, Trust and Legitimacy}

There is a widespread understanding supported by empirical evidence that independence is necessary for the judiciary to gain the confidence of society and that a high level of confidence bolsters the legitimacy of the judiciary in the sense of its licence to operate. Confidence and legitimacy are seen as essential for the courts to fulfil their function. In the judgment of the Court of Justice of the European Union that was already cited about independence in Sect. 2.1, the court continues: “... 
it being added, in that connection, that what is at stake is the confidence which such tribunals must inspire in the public in a democratic society." And similarly with regard to impartiality: "Once again, what is at stake is the confidence which the courts in a democratic society must inspire in the public, and first and foremost in the parties to the proceedings". In the same vein, Lenaerts sees independence and impartiality as necessary for court rulings to enjoy authority and legitimacy (Lenaerts 2020, p. 31). In these wordings independence and impartiality are instrumental to achieve the confidence in and authority and legitimacy of the courts. This is strongly felt by others in the field as well, to such an extent that it has become a common understanding. It also adds another aspect to the importance of independence as perceived in society. Before we look into these causal relationships, we need to discuss briefly the different concepts used in the literature and their meaning.

\subsubsection{Trust and Legitimacy}

Trust, legitimacy and related concepts apply to public institutions in general, but have also been examined with specific reference to the courts. As Hamm et al. (2011) notes, in the literature about the judiciary in its connection with society terms like confidence, trust, trustworthiness, public support, loyalty, legitimacy and felt obligation to obey the law as well as negatively charged notions like scepticism, cynicism and distrust are used. These diffuse concepts are often used interchangeably but they are sometimes defined distinctly. Also, in the vast literature on trust a variety of types of trust is distinguished, such as dispositional trust (as a basic individual attitude), interpersonal trust, institutional trustin diffuse form (trust in an institution in general) and specific form (trust in an institution to do something specific such as uphold the law) - and political trust. To complicate matters, the trust of a person in an institution may be evolving, depending on information and experience gained. For instance in the case of the judiciary, if a person has no experience with the courts or even with government in general, the person will exhibit his dispositional trust when asked whether he trusts the courts. Once he has experiences with the public sector, dispositional trust will be replaced by institutional trust that he will apply to the courts as well. After concrete experience with the courts, diffuse and specific trust in the courts may take over (Mayer et al. 2006). Linguistically, some of these concepts do not travel well: for instance confidence and trust translate into the same 
term in German and Dutch (an easy check is to compare the cited case law in different languages as available at the website of the CJEU). Relevant in the current context is also that trust can be defined as perceived trustworthiness of somebody or an institution, but can also be seen to relate to trusting behaviour. The latter involves giving up power to another over outcomes that are important for oneself. In this approach trust is more than a passive evaluation without obligation. This interpretation applies in particular to the interpersonal level (Tanis and Postmes 2005), but it is also relevant for trust in the courts. This is obviously the case when deciding to go to court: one gives up willingly or unwillingly control over one's situation (see Benesh 2006). A person puts his fate in the hands of the court, and expects that it gets fair treatment. Finally, trust is also sometimes used in the sense that an actor is trusted to behave in a certain way (Mayoral 2017): the actor behaves as expected, for instance by doing what is in his (narrow) self-interest.

The Court of Justice uses, as the quote before shows, the term confidence in the courts. Confidence is also used in much research about the US (GBAO 2020; Benesh 2006; Hamm et al. 2011). Public opinion surveys by the EC use the term trust (EC 2020b). Also in view of the linguistic issues, trust in the courts and confidence in the courts are used interchangeably here.

Trusting behaviour in the courts is close to other concepts such as felt obligation to obey the law (Hamm et al. 2011), but also, more recently, to respect for the independence of the courts (ENCJ 2019). Both concepts are related to institutional legitimacy and the public's compliance with institutions (Tyler and Sevier 2013/2014). Felt obligation to obey is either seen as part of legitimacy or as an outcome of legitimacy (Tyler and Huo 2002; Tyler and Jackson 2014; Gibson and Caldeira 1998). In an experimental study among students, Hamm et al. (2011) finds separable effects on overall confidence in the courts in general of dispositional trust, trust in institutions, obligation to obey the law and cynicism. In the following the terms trust/confidence, in the sense of diffuse trust, and respect for judicial independence as a consequence of institutional (judicial) legitimacy are used. It is unfortunate that surveys that focus on negative concepts such as cynicism are currently not available for Europe, as such data would provide a valuable complement (Tyler and Huo 2002).

While the surveys about independence and respect for independence among judges, lay judges and lawyers have been developed by the ENCJ recently, with regard to trust recourse has to be taken to existing opinion 
surveys, and the questions as phrased in these surveys, have to be accepted. For instance, the opinion survey of the European Commission asks: "Do you tend to trust the judicial/legal system?" This phrase leaves very much open. Do respondents answer the question whether courts are trustworthy or whether they are willing to relinquish control by bringing their disputes to court? Given the limited experience of citizens with the courts, answers are also likely to reflect a combination of dispositional trust, trust in government in general and trust in the courts.

\subsubsection{Empirical Relationship Between Independence and Trust}

The connection between independence on the one hand and confidence or trust on the other hand can now be considered. It was already noted that it is the clear view of the Court of Justice of the European Union that independence as well as impartiality lead to confidence in the courts. Empirical studies confirm the connection between independence and confidence. Benesh (2006) in a key study about the State Courts in the US, based on a survey by the National Center for State Courts, hypothesizes that procedural justice, implying a fair arbiter, as well as the institutional design of the courts related to independence affect confidence, in addition to type of experience (party or juror). In the American context institutional design concerns whether judges are appointed or elected. The hypothesis is that elected judges who have to campaign for election are less independent than appointed judges. Both hypotheses (procedural justice and independence) hold. Cann and Yates (2008) finds that judicial elections and judicial campaign contributions undermine support for the US state courts. Support is measured by among other perceptions of the trustworthiness of judges and whether decisions are perceived to be based on facts and law. Citizens are concerned about costly, partisan election campaigns. Cann and Yates finds that more independence leads to higher confidence. It finds also that citizen characteristics, race and gender and social capital, play a role. Intriguingly, greater knowledge of the legal system reduces the perception of court legitimacy. The study suggest that a realistic view on the functioning of the court leads to a less positive perception, and confidence evolves into a more instrumental opinion based on specific outcomes.

Buhlmann and Kunz (2011) examines the impact of the independence of the judiciary on the confidence of citizens in the justice system by means of a multi-level analysis for a range of countries, using data from 
diverse sources. The study finds that the perceptions of judicial independence in society are formed by actual (de facto) independence and not (directly) by the formal rules and safeguards that protect the independence of the judiciary, de iure independence, and that these perceptions foster confidence in the judicial system. Contrary to expectations, it also finds that political and economic 'winners' have greater confidence in the judiciary than 'losers', irrespective of degree of independence. The study suggests that independence gives judges the opportunity to decide matters according to their ideological views or in an arbitrary way, but other explanations are conceivable. For instance, 'winning' and 'losing' may be related to level of education. In the next Chapter the impact of education on perceptions of independence is examined. It has been suggested furthermore that there is a causal relationship between the existence of impartial institutions in a broad sense and generalized (dispositional) trust, but the evidence is not conclusive (Rothstein and Stolle 2008).

More specifically, Sapignoli (2018) uses the Eurobarometer public opinion surveys of the EU to find that the perceived independence of magistrates is strongly correlated with the trust of citizens in the judicial system, and even more so than the effectiveness of the judicial system in guaranteeing the rule of law. These opinion surveys will be examined in Chapter 6. Finally, experimentally the relationship between impartiality as part of procedural justice and trust has been established (Grootelaar and van den Bos 2018). As discussed before, independence and impartiality are closely connected.

To conclude, trust in the judiciary seems to be equal to trust in the independence of the judiciary. While independence is particularly relevant for the judiciary (but not only for the judiciary, see below), trust in the judiciary can be compared with that in the other state powers (Chapter 6).

Having established the link between independence and trust, the statement of the Court of Justice, quoted earlier, requires further attention. Its underlying premise is that the judiciary needs the trust of the population to be able to function. Why is it necessary for the judiciary to be trusted? Is this trust functional and does it add anything to the perception of independence? This seems a rather trivial question, but the reasoning is of some interest. While the importance of trust holds true for the other powers of the state as well in a democracy, for the judiciary this is often seen as particularly important. The main arguments are well known: (1) as mentioned earlier, in most fields of law parties have a choice to bring 
their disputes to court, do nothing or pursue different courses of action, and, once having gone to court and having received judicial decisions, the enforcement of the judgments is external to the judiciary, and (partly) depends on parties accepting the authority of the courts (Tyler and Sevier 2013/2014). This applies to criminal law as well: trust affects willingness to report crimes and for witnesses to cooperate with the police (Tyler and Huo 2002; Warner et al. 2014). Also, the acceptance of judgements in general, even when unpopular, is greater when diffuse support is higher (Gibson et al. 2005). (2) Lacking direct democratic legitimation and being dependent on the other state powers in many respects for instance for funding, the judiciary is vulnerable to encroachment by the other state powers (Cann and Yates 2008; Rehnquist 2000; Langer 2002). Attacking an institution that is trusted widely, may undermine one's own position, and thus backfire.

While both arguments raise complications which will be discussed in Chapter 7, the essence that the courts need trust to function, is not contested in the literature. It is, however, an open question how this works in practice.

\subsection{BEHAVIOUR OF THE JUDICIARY TO ENHANCE INDEPENDENCE}

The second argument (position in trias politica) reverses the relationship between trust and independence. A judiciary that is trusted in society, stands a better chance to get - wholeheartedly or grudgingly-from politics the independence it existentially needs to function or it is more immune to attempts of infringement. The judiciary therefore has an incentive to build trust, in as far as this is within its powers. Given the link with independence, this is not necessarily doing what people think is desirable, such as heavier sentences for crimes always and everywhere. The choice judiciaries face is to build either diffuse or specific support. It has been shown in a study for the Netherlands that citizens feel that sentences are too lenient, but that they also think that judges should be independent, and should decide at they do (de Keyser et al. 2007). Thus, society wants judicial independence, and that is what is trusted.

This chain of effects from building trust in the judiciary among the general public to strong support in government and parliament for the judiciary is not trivial, especially given the decentralized and nonhierarchical nature of the judiciary. What may work for the public, may 
not necessarily work in politics. These processes are not only occurring with regard to the judiciary. The public sector has seen a-what is called-agencification (Papadopoulos 2013). Traditional government bureaucracies have been replaced by single-purpose organizations that implement specific laws and regulations. These agencies have a high degree of autonomy or even independence to shield them from partisan political influence. The development of the literature in political science about these autonomous agencies is of interest here. A major review of this literature identifies as an important trend increased attention for agency autonomy as 'a dynamic, relational and socially constructed phenomenon' (Verhoest 2017). In this approach autonomy, reputation and trust are linked. It suggests that agencies can gain more autonomy or defend their autonomy by developing a strong reputation with relevant actors and by creating a strong network of support for the agency.

This thinking applies to the judiciary as well, while recognizing that independence is more fundamental for the functioning of the judiciary than autonomy is for agencies. Obviously, the actual independence of the courts is not a static characteristic of a legal system (de iure independence), as the cases of Poland and Hungary graphically show (e.g. Coman 2014; Kovács and Scheppele 2018). Strong legal foundations of independence can be lost in the course of a few years. The case of Poland in particular highlights that legal safeguards do not always offer protection, as relevant laws have been changed relatively easily and rapidly there. Following the reasoning of this political science literature, protection does not come from existing laws or even the constitution, but from excellent performance for the court users and active policies to build support. The trust and reputation of the judiciary are then aspects that strengthen or weaken the position of the judiciary. While active networking would also be effective, in the judiciary this meets often with resistance, as courts keep and treasure their distance from other organisations, just to protect their independence. Still, bar associations and civil society are often natural allies. However, with these constraints on networking and lobbying, building trust and support of the general public seems to be particularly important for the judiciary.

These arguments strengthen the relevance of the subject matter of this book, as perceptions about the judiciary in society may play an even more crucial role than laws and formal safeguards. An open question is whether judiciaries are looking at their position in this way. Do they have governance structures that allow them to work on their reputation consciously 
and in a co-ordinated manner or can the same results be achieved by synchronized behaviour of individual judges? These issues are beyond this book.

\subsubsection{Multi-level Governance}

In his review Verhoest (2017) emphasizes that the relational aspect of autonomy also concerns the multi-level governance structure within the EU. National political decision makers have to take into account the policies of the EU. As Braithwaite and Drahos (2000) put it, nations are rule-takers rather than rule-makers. Multi-level governance is obviously relevant for the judiciary in view of the presence of courts at the European level, to which was referred already several times. In the EU legal order, the hierarchy of institutions, if it is appropriate to use this term, is stronger with regard to the courts than with regard to the other state powers, in as far as the mandate of the EU is concerned and it is uncontested. National judges are also European judges and national courts are decentralized courts, applying EU law and European standards. National judges ask for guidance of the Court of Justice of the European Union. In the case of Poland about the independence of the judiciary, the influence exerted by institutions at the European level on national institutions is particularly observable, where the European Court of Justice and the European Court of Human Rights play an important role next to the political institutions of the EU (Kovács and Scheppele 2018). This case is an illustration of the interaction of levels of governance: the Court of Justice intervenes directly in national policies and legislation, and instructs the authorities to take measures. At the end of the day, however, if countries do not abide by its decisions, the court depends on the European Commission in particular to enforce its judgments. The EC promotes and tries to maintain the independence of national judiciaries and the stability of the division of powers in all member states. The Justice Scoreboard of the EC is an example of a monitoring mechanism (EC 2020a). Given this structure, the interaction mechanism suggested above repeats itself at the EU-level. Independence, trust, legitimacy and respect for independence all play a role. The trust of the national populations in the EU institutions and the perceptions about the independence of the Court of Justice of the European Union and European Court of Human Rights are relevant for the functioning of the whole multi-level system. 
The EU level adds a dimension to the independence of and trust in the judiciary, as national judges have opinions about the independence of the EU-courts and have a degree of trust in them, and vice versa. Also, national judges have views about the independence of judges in other member states and their trustworthiness. These issues have been dealt with by others (Mayoral 2017), but also need more data to be gathered. The focus here is on the actual alignment or lack of alignment of judiciary and society in Europe, as basis for the judiciary to fulfil its mandate to provide effective protection of rights using the terminology of the Court of Justice.

\subsection{Alignment of Judiciary and Society}

Judicial independence is still often seen as stemming from the formal arrangements in law and constitution, and as static as long as the legal provisions remain the same. However, legal provisions are subject to change, and need to be stabilized, if one wants to maintain them as they are. The independence of the judiciary is permanently constructed by the behaviours of many actors, and is inherently dynamic. The simplified scheme below captures the main concepts. While trust and legitimacy may be empirically hard to distinguish, there is a case to be made to distinguish them. One can trust the judiciary fully, and still be of the opinion that the judiciary lacks legitimacy, in particular democratic legitimacy. Also, the judiciary may have democratic legitimacy, for instance by means of election of judges, but this may affect, as discussed above, perceived independence negatively, and this impacts trust negatively as well.

Perceived judicial independence $\leftrightarrow \quad$ Trust in judiciary

$\uparrow$

Respect of judicial independence $\leftrightarrow$

Legitimacy of the judiciary

The main causal direction is probably clockwise, but causality also runs the other way, as discussed in the previous section. A major issue is whether the system that is represented by the scheme, is in equilibrium. 
Equilibrium may arise out of virtuous and negative cycles. How equilibria would look like, and what their stability is, is a huge subject in itself. In Chapter 7, this subject will be briefly discussed.

It must be emphasized that all four concepts are likely to be specific for categories of actors. Respect for judicial independence is a clear case in point. Respect is likely to differ among categories of actors, such as the court users (parties and their lawyers, prosecutors), the political system (parliament, government and the media), but also actors within the judiciary (supreme court, court management and councils for the judiciary). These categories have different involvements with the judiciary and different interests and motivations. While for politicians respect for independence ideally means no interference with the judiciary, proper implementation of judicial decisions, seeing to it that the resources of the judiciary are adequate and reluctance to criticize the judiciary, and for the media substantive, factual reporting of court cases and refraining from personal attacks (such as 'enemies of the people'), for parties, lawyers and prosecutors it would mean not to resort to inappropriate behaviours (attempts to bribe judges, threaten judges), but to implement judicial decisions if there is the choice not to do so, and to exert democratic rights to support the judiciary. Within the judiciary itself, respect would mean for court management and councils for the judiciary not to put pressure on judges to adjudicate cases, for instance, from an efficiency point of view. This reasoning applies to all four concepts of the scheme. However, the availability of data is a limiting factor. Table 2.1 gives the differentiation that is applied in the next Chapters.

Another aspect of the data is from which perspective perceptions are measured. One can ask, for instance, citizens about their perceptions of judicial independence, but one can also ask judges how they think citizens perceive judicial independence. Taking the perspective of the behavioural reactions of the judiciary as in previous sections, the perceptions of judges of how society perceives its independence and whether relevant groups in society respect judicial independence are particularly relevant. However, perceptions about perceptions become quickly complicated. In this book all data are based on first order surveys, except for respect for judicial independence. It does not make much sense to ask people whether they respect the independence of the judiciary if one wants to avoid socially desirable answers, but it makes sense to ask judges whether they feel their independence is respected, as they experience this directly in the courts. This leads also to some complications, as will be discussed in Chapter 5 . 
Table 2.1 Overview of perceptions and comparisons (arrows) that are presented

\begin{tabular}{|l|l|l|}
\hline & National institutions & EU institutions \\
\hline Perceived judicial & $\begin{array}{l}\text { Perceptions of: } \\
\text { independence }\end{array}$ & $\begin{array}{l}\text { - General public } \\
\text { - Companies } \\
\text { - Lawyers } \\
\text { - Judges } \\
\text { - Lay judges } \\
\text { - Parties }\end{array}$ \\
\hline $\begin{array}{l}\text { Perceived respect of } \\
\text { independence }\end{array}$ & $\begin{array}{l}\text { Respect of judicial independence, } \\
\text { as perceived by judges, by: } \\
\text { - Parliament } \\
\text { - Government } \\
\text { - Media } \\
\text { - Judicial institutions } \\
\text { - Lawyers } \\
\text { - Parties }\end{array}$ & \\
\hline Trust & $\begin{array}{l}\text { Trust by general public in: } \\
\text { - Courts } \\
\text { - Parliament } \\
\text { - Government } \\
\text { - Other public institutions }\end{array}$ & \\
\hline
\end{tabular}

The differentiation of categories of stakeholders is an essential part of this study. The alignment of judiciary and society shows not only in the extent society in a broad sense is convinced of the independence of the judiciary and trusts its judiciary, but also in the extent that the perceptions of the functioning of the judiciary among judges and (groups in) society differ. The relevance of differences in perceptions of judges and the (potential) users of the courts in a broad sense comes to the fore in particular when judges are much more positive than society about their performance. Such differences feed the feeling in society that judges are otherworldly, live in an ivory tower and are protective of their position. To be satisfied about oneself, while the court users are unhappy, is likely to have negative consequences for trust. In addition, perceptions drive behaviour, causing a tendency not to see a need for change within the judiciary, where others outside the judiciary see this need as urgent. See Rottman and Tomkins (1999) which notes for the US state courts a large 
difference in the appreciation of the functioning of the courts between population and judges with judges not seeing a need for change. Finally and as a consequence, differences may create tensions and strife among the state powers. Large (unexplained) differences in perceptions of judicial independence may tempt the other branches to intervene or to strengthen their grip on the judiciary. In the next Chapters, while filling in Table 2.1, the focus will be on differences.

\section{REFERENCES}

Ashenfelter, O., T. Eisenberg, and S.J. Schwab. 1995. Politics and the judiciary: The influence of judicial background on case outcomes. Journal of Legal Studies 24 (2): 257-281.

Baumeister, R.F., E. Bratslavsky, C. Finkenauer, and K.D. Vohs. 2001. Bad is stronger than good. Review of General Psychology 5 (4): 323-370.

Benesh, S.C. 2006. Understanding public confidence in American courts. Journal of Politics 68 (3): 697-707.

Braithwaite, J., and P. Drahos. 2000. Global business regulation. Cambridge: Cambridge University Press.

Buhlmann, M., and R. Kunz. 2011. Confidence in the judiciary: Comparing the independence and legitimacy of judicial systems. West European Politics 34 (2): 317-345.

Cann, D.M., and J. Yates. 2008. Homegrown institutional legitimacy; Assessing citizens' diffuse support for State Courts. American Politics Research 36 (2): 297-329.

CEPEJ. 2016. Handbook for conducting satisfaction surveys aimed at court users in Council of Europe member states, 2018 edition (2016 data). https://rm. coe.int/168074816f.

Coman, R. 2014. Quo vadis judicial reform? The quest for judicial independence in Central and Eastern Europe. Europe-Asia Studies 66 (6): 892-924.

de Keijser, J., P. van Koppen, and H. Elffers. 2007. Bridging the gap between judges and the public? A multi-method study. Journal of Experimental Criminology 3: 131-161.

ENCJ. 2019. Independence and accountability of the judiciary: ENCJ Survey on the independence of judges 2019. encj.eu.

ENCJ. 2020. Independence, accountability and quality of the judiciary: Measuring for improvement. ENCJ Report 2019-2020. encj.eu.

European Commission. 2020a. 2020 EU Justice Scoreboard.

European Commission. 2020b. Eurobarometer Interactive, Public opinion survey. https://ec.europa.eu/commfrontoffice/publicopinion/index.cfm/ Chart/index. 
GBAO. 2020. State of the State Courts, Survey analysis.

Gibson, J.L., and G. Caldeira. 1998. Changes in the legitimacy of the European Court of Justice: A post-Maastricht analysis. British Journal of Political Science 28: 63-91.

Gibson, J.L., G. Caldeira, and L.K. Spence. 2005. Why do people accept public policies they oppose? Testing legitimacy theory with a survey-based experiment. Political Research Quarterly 58: 187-201.

Grootelaar, H.A.M., and K. van den Bos. 2018. How litigants in Dutch courtrooms come to trust judges: The role of perceived procedural Justice, outcome favorability, and other sociolegal moderators. Law and Society Review 52 (1): 234-267.

Hamm, J.A., L.M. PytlikZillig, A.J. Tomkins, M.N. Herian, B.H. Bornstein, and E.M. Neeley. 2011. Exploring seperable components of institutional confidence. Behavioral Sciences of the Law 29: 95-115.

Johnston, C.D., and B.L. Bartels. 2010. Sensationalism and sobriety; Differential media exposure and attitudes toward American courts. Public Opinion Quarterly 74 (2): 260-285.

Kahneman, D., and A. Tversky. 1984. Choices, values, and frames. American Psychologist 39: 341-350.

Kovács, K., and K. Scheppele. 2018. The fragility of an independent judiciary: Lessons from Hungary and Poland-And the European Union. Communist and Post-Communist Studies 51: 189-200.

Langer, L. 2002. Judicial review in state supreme courts: A comparative study. Albany: State University of New York Press.

Lenaerts, K. 2020. New horizons for the rule of law within the EU. German Law Review 21: 29-34.

Mayer, R.C., J.H. Davis, and F.D. Schoorman. 2006. An integrative model of organizational trust. In Organizational trust: A reader, ed. R.M. Kramer, 82-108. New York: Oxford University Press.

Mayoral, J.A. 2017. Impact through trust: the CJEU as trust-enhancing institution. iCourts Working Paper 105.

OHCHR. 1985. Basic principles on the independence of the judiciary. https:// www.ohchr.org/EN/ProfessionalInterest/Pages/IndependenceJudiciary.aspx.

OHCHR. 2003. Human rights in the administration of justice: A manual on human rights for judges, prosecutors and lawyers.

Papadopoulos, Y. 2013. Democracy in crisis? Politics, Governance and Policy. Cham: Palgrave Macmillan.

Regioplan and Ipsos. 2015. Klantwaardering Rechtspraak 2014.

Rehnquist, W.H. 2000. Reflections on the history and future of the Supreme Court of the United States. Speech at the D.C. Circuit Judicial Conference.

Rothstein, B., and D. Stolle. 2008. The state and social capital: An institutional theory of generalized trust. Comparative Politics 40 (4): 441-459. 
Rottman, D.B., and A.J. Tomkins. 1999. Public trust and confidence in the courts: What public opinion surveys mean to judges. Court Review 36 (3): $24-31$.

Sapignoli, M. 2018. Trust in justice in EU countries: Level of support and correlated factors. Paper prepared for 2018 EGPA Conference, Study Group XVIII on Justice and Court Administration.

Tanis, M., and T. Postmes. 2005. A social identity approach to trust: interpersonal perception, group membership and trusting behaviour. European Journal of Social Psychology 35: 413-424.

Tyler, T.R., and J. Sevier. 2013/2014. How do the courts create popular legitimacy? The role of establishing the truth, punishing justly and/or acting through just procedures. Albany Law Review 77(3): 1095-1137.

Tyler, T.R., and Y.J. Huo. 2002. Trust in the law: Encouraging public cooperation with the police and the courts. New York: Russell-Sage Foundation.

Tyler, T.R., and J. Jackson. 2014. Popular legitimacy and the exercise of legal authority: Motivating compliance, cooperation, and engagement. Psychology, Public Policy, and Law 20: 78-95.

van Dijk, F., J. Sonnemans, and F. van Winden. 2002. Social ties in a public good experiment. Journal of Public Economics 85: 275-299.

Venice Commission. 2020. Poland, Joint urgent opinion of the Venice Commission and the Directorate General of Human Rights and Rule of Law of the Council of Europe, Opinion No. 977/2019.

Verhoest, K. 2017. Agentification. In The Palgrave Handbook of Public Administration and Management in Europe, ed. E. Ongaro and S. van Thiel, 327-346. Basingstoke: Palgrave Macmillan.

Warner, K., J. Davis, M. Walter, and C. Spiranovic. 2014. Are judges out of touch? Current Issues in Criminal Justice 25 (3): 729-744. 
Open Access This chapter is licensed under the terms of the Creative Commons Attribution 4.0 International License (http://creativecommons.org/licenses/ by $/ 4.0 /$ ), which permits use, sharing, adaptation, distribution and reproduction in any medium or format, as long as you give appropriate credit to the original author(s) and the source, provide a link to the Creative Commons license and indicate if changes were made.

The images or other third party material in this chapter are included in the chapter's Creative Commons license, unless indicated otherwise in a credit line to the material. If material is not included in the chapter's Creative Commons license and your intended use is not permitted by statutory regulation or exceeds the permitted use, you will need to obtain permission directly from the copyright holder.

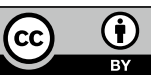

